\title{
Optimization of preparation process and performance analysis of fly ash foam glass
}

\author{
Zipeng Qin, Gang Li, Yan Tian, Yuwei Ma, Pengfei Shen \\ College of Water Conservancy and Architectural Engineering, \\ Shihezi University, Shihezi 832000, China
}

Received April 18, 2018

Foam glass was prepared with fly ash and glass powder as main raw materials, sodium
arbonate as foaming agent, and trisodium phosphate as suds-stabilizing agent. The influ-
nce of the amount of fly ash and sodium carbonate, foaming temperature and foaming
ime on the compressive strength, flexural strength, apparent density and thermal conduc-
ivity of foam glass was studied by orthogonal experiment and the optimum technological
onditions for preparing foam glass were obtained. The pore structure, morphology, pore
ize distribution, morphology and crystal precipitation of foam glass were investigated by
means of Occhio Scan v750, Nano Measurer, SEM and XRD. The result shows that the
mount of fly ash has a significant influence on the mechanical and thermal conductivity
f foam glass, the foaming temperature has the greatest influence on the apparent density,
nd the influence of sodium carbonate content on the average pore size is the most
bvious. The pore numbers of 9 sets of samples are approximately normal distribution
with the change of average pore sizes, and the average pore sizes of 0.1-2.0 mm exceed
$85 \%$ There is a certain amount of crystal precipitating inside the foam glass and the
major and secondary crystalline phase are nepheline and diopside respectively.
Keywords: porous structure, foaming temperature, foaming time, foaming agent, fly ash, foam glass.

Пеностекло приготовлено на основе летучей золы и стеклянного порошка с добавками вспенивающего агента карбоната натрия и стабилизирущего пенообразование тринатрийфосфата. Влияние количества летучей золы и карбоната натрия, температуры вспенивания и времени вспенивания на прочность к сжатию и на изгиб, плотность и теплопроводность пеностекла исследовали с помощью ортогонального плана эксперимента, в процессе которого установлены оптимальные технологические условия его получения. Применяя Occhio Scan v750, Nano Measurer, SEM и XRD изучена структура пор, морфология, распределение пор по размерам и образование кристаллической фазы пеностекла. Установлено, что на механическую прочность и теплопроводность пеностекла оказывает значительное влияние количество летучей золы, а на плотность температура вспенивания. Показано, что средний размер пор зависит от содержания карбоната натрия. В 9 видах образцов распределение общего количества пор по размерам соответствует нормальному, число пор со средними размерами 0,1-2,0 мм превышает $85 \%$. Внутри пеностекла находится определенное количество кристаллического материала, причем основная и вторичная кристаллические фазы являются нефелином и диопсидом соответственно.

Оптимізація процесу підготовки та аналіз технічних характеристик піноскла 3 летючої золи. Zipeng Qin, Gang Li, Yan Tian, Yuwei Ma, Pengfei Shen

Піноскло виготовлено на основі летючого попелу і скляного порошку з добавками карбонату натрію у якості агента для спінювання і тринатрійфосфату, що стабілізує піноутворення. Вплив кількості летючого попелу і карбонату натрію, температури $\mathrm{i}$ часу спінювання на міцність до стиску, та вигин, щільність і теплопровідність піноскла 
досліджено з використанням ортогонального плану експерименту, у процесі якого встановлено оптимальні технологічні умови його отримання. За допомогою Occhio Scan v750, Nano Measurer, SEM i XRD вивчено структуру пор, морфологію, розподіл пор за розмірами та створення кристалічної фази піноскла. Встановлено, що на механічну міцність і теплопровідність піноскла значно впливає кількість летючого попелу, на щільність - температура спінювання, а середній розмір пор залежить від вмісту карбонату натрію. У 9 видах зразків розподіл загальної кількості пор за розмірами відповідає нормальному, число пор із середніми розмірами 0,1-2,0 мм перевищує 85\%. Усередині піноскла знаходиться певна кількість кристалічного матеріалу, причому основна і вторинна кристалічні фази є нефеліном і диопсидом відповідно.

\section{Introduction}

Fly ash foam glass has been widely used in the fields of building, water conservancy and traffic roads as heat insulation material, light filling material, sound insulation sound absorption material and lightweight concrete aggregate. This porous lightweight material is made of fly ash and glass powder as the main raw material by firing through stages of preheating, melting, foaming, foam stabilization and annealing [1-4]. Fly ash foam glass has the advantages of high mechanical strength, small thermal conductivity, nonflammable (grade A nonflammable material), high softening temperature, good thermal stability and chemical stability, good sound insulation effect, strong corrosion resistance, and free from insect pests, etc. [5-11]. However, due to the improper control of material mixing ratio and firing process in the production of foam glass the pores in the products are unevenly distributed, the average aperture is very discrete, the number of communication pores is large and the surface are rugged and many other defects, and these defects will seriously affect the physical and mechanical properties of foam glass [12,13]. Therefore, the optimization and performance analysis of the preparation process are of great significance to the production of high-quality foam glass.

Bo Chen et al. [14] showed that the sintered fly ash foam glass at $800^{\circ} \mathrm{C}$ had excellent comprehensive properties. Zipeng Qin et al. $[15,16]$ considered that the amount of fly ash had great influence on the strength, apparent density, porosity and thermal conductivity of foam glass, while the foaming temperature and foaming time had remarkable influence on the pore structure and porosity distribution. Shuai Qian et al. [17] showed that the pore structure of foam glass with 70 mass \% fraction of municipal solid waste incinerator ash and $\mathrm{CaCO}_{3}$ as foaming agent become uniform and the apparent density decreased in a certain range with the increase of firing temperature. The aperture of foam glass gradually increased, the apparent density decreased with the foaming agent content increased from $0.5 \%$ to $2.5 \%$. The change trend of compressive strength was basically consistent with the pore structure and apparent density. Yingliang Tian et al. [18] showed that insufficient cooling rate in the process of rapid expansion could not make the surface tension and viscosity of glass melt react with each other, which does not match the glass melt and gas expansion or contraction and resulted in foam glass surface depression. $\mathrm{Yu}$ Zhou, Huan Shi et al [19, 20] showed that the pore size of the foamed glass increased with the increase of sintering temperature, increased first and then decreased with the increase of the content of aluminum nitride. It is easy to form large pores and connected pores in the products with the increasing temperature and the increasing foaming agent content, and the degree of crystallization and crystal type had great influence on the strength of the sample.

In this paper, the compressive strength, flexural strength, apparent density and thermal conductivity were taken as the experimental indexes in designing of $\mathrm{L}_{9}\left(3^{4}\right)$ orthogonal experiment to optimize the preparation process and to investigate the effects of different factors on the properties of foam glass from fly ash and glass powder, $\mathrm{Na}_{2} \mathrm{CO}_{3}$ (foaming agent) and $\mathrm{Na}_{3} \mathrm{PO}_{4} \cdot 12 \mathrm{H}_{2} \mathrm{O}$ (stabilizer). The research can provide some reference for the production and engineering application of fly ash foam glass.

\section{Experimental}

\subsection{Experiment raw material}

Fly ash produced in Xinjiang Tianye (Group) power plant. The raw material of glass powder is the waste flat glass collected from a glass shop in Shihezi and it was thoroughly dried and placed into a roller ball mill for ball milling over 2 hours after washing, and was filtered through 200 mesh screens (aperture $0.074 \mathrm{~mm}$ ). The chemical composition and physical indexes 
Table 1. Chemical composition and physical indicators of fly ash and glass powder

\begin{tabular}{|c|c|c|c|c|c|c|c|c|}
\hline \multirow[t]{2}{*}{ Designation } & \multicolumn{6}{|c|}{ Mass fraction, $\%$} & \multirow{2}{*}{$\underset{\%}{\text { Fineness, }}$} & \multirow{2}{*}{$\begin{array}{l}\text { Loss on ig- } \\
\text { nitio, \% }\end{array}$} \\
\hline & $\mathrm{SiO}$ & $\mathrm{Al}_{2} \mathrm{O}_{3}$ & $\mathrm{Fe}_{2} \mathrm{O}_{3}$ & $\mathrm{CaO}$ & $\mathrm{MgO}$ & $\mathrm{K}_{2} \mathrm{O}+\mathrm{Na}_{2} \mathrm{O}$ & & \\
\hline Fly ash & 59.84 & 30.77 & 3.30 & 1.84 & 2.35 & 1.90 & 4.70 & 4.90 \\
\hline Waste glass & 72.33 & 1.40 & 0.15 & 8.62 & 4.72 & 12.78 & - & - \\
\hline
\end{tabular}

of fly ash and glass powder are shown in Table 1 . The foaming agent is made of sodium carbonate (analysis pure, $\mathrm{Na}_{2} \mathrm{CO}_{3}$ content is $99.5 \%$ ), produced by Tianjin Zhiyuan Reagent limited company. The stabilizer is sodium phosphate tertiary (analysis pure, $\mathrm{Na}_{3} \mathrm{PO}_{4} 12 \mathrm{H}_{2} \mathrm{O}$ content is above $98 \%$ ), produced by Tianjin Zhiyuan Reagent limited company. The mold discharging agent is Boron nitride parting spray (model: JD-3028AAA).

\subsection{Sample preparation}

The fly ash, glass powder and sodium phosphate tertiary were weighed according to a certain proportion, and then were stirred into the cement mortar mixer to stir 2 3 minutes. The prepared sodium carbonate solution was weighed and added slowly, and the mixture was put into the mold after stirring for 2 3 $\mathrm{min}$. The mold was placed on the vibrating table of the concrete and was vibrated about 3 minutes, and then it was dried in the oven to obtain the body of foam glass. $1.0 \sim 1.5 \mathrm{~cm}$ refractory sand was laid on the bottom of the resistance furnace to make the body heated uniformly. The temperature control of the firing process was divided into 4 stages as follows[22]. Preheating stage: the temperature is increased from room temperature to $400{ }^{\circ} \mathrm{C}$ at a rate of $5 \sim 8^{\circ} \mathrm{C} / \mathrm{min}$ and the temperature was maintained for 20 30 minutes to remove the binding water and adsorbed water in raw material, so as to prevent the influence of water vapor on foaming during heating. Melting stage: The body was heated to $650 \sim 750^{\circ} \mathrm{C}$ at a rate of $8 \sim 10^{\circ} \mathrm{C} / \mathrm{min}$, which softened the body rapidly and reduced the gas escaping as much as possible. Foaming stage: the temperature was increased to $850 \sim 870^{\circ} \mathrm{C}$ at a rate of $10 \sim 15^{\circ} \mathrm{C} / \mathrm{min}$, and the foaming time was $20 \sim 30 \mathrm{~min}$, which caused the foaming agent to react rapidly and produce a large amount of bubbles. Bubble stabilization and annealing stage: the temperature was reduced to $500 \sim 600^{\circ} \mathrm{C}$ at a rate of $15 \sim 20^{\circ} \mathrm{C} / \mathrm{min}$ and was kept for $20 \sim 30 \mathrm{~min}$ to settle down the formed bubbles quickly and maintain the just formed pore structure of the foam. Then the furnace was turned off and the sample was taken out after the sam- ple temperature was naturally reduced to room temperature in the furnace.

\subsection{Instrumental analysis}

Phase analysis of the sample was carried out using a D8 ADVANCE $X$ ray diffractometer produced by Brook AXS company, the scanning rate was $5^{\circ} / \mathrm{min}$ and scan range (2 theta) was $10 \sim 80^{\circ}$. Occhio Scan 600 was used to scan the pore structure of $20 \times 20 \mathrm{~mm}^{2}$ area on the geometric center of the samples and particle size analysis software Nano Measurer was used to calculate the number and size of apertures. S-4800 type scanning electron microscopy produced by Hitachi was utilized to observe the morphology of foam glass, and some samples were observed with this scanning electron microscope after they were corroded in $2 \% \mathrm{HF}$ solution for $45 \mathrm{~s}$. The apparent density of the samples was determined by Archimides method. The compressive and flexural strength of the samples were tested by NY-60 hydraulic pressure tester and TYE-6A cement mortar bending test machine, before the test, the compressive and flexural specimens were respectively cut into $40 \times 40 \mathrm{~mm}^{2}$ and $40 \times 40 \times 160 \mathrm{~mm}^{3}$ sizes, and the same sample was tested 3 times and the average value was taken as the test result. The thermal conductivity of samples was measured by JTRG-III heat flow meter type heat conduction instrument produced by Beijing Jiantong Century Environmental Technology Co Ltd.

\subsection{Orthogonal experimental design}

The content of fly ash, the content of sodium carbonate, foaming temperature and foaming time were selected as the main factors that were respectively expressed as $\mathrm{F}$, $\mathrm{C}, \mathrm{T}$, and $\mathrm{S}$, and the compressive strength, flexural strength, apparent density and thermal conductivity were taken as the test indexes. The factors and levels of L9(34) orthogonal test are shown in Table 2 .

\section{Results and discussion}

The results of $\mathrm{L}_{9}\left(3^{4}\right)$ orthogonal test are shown in Table 3. 

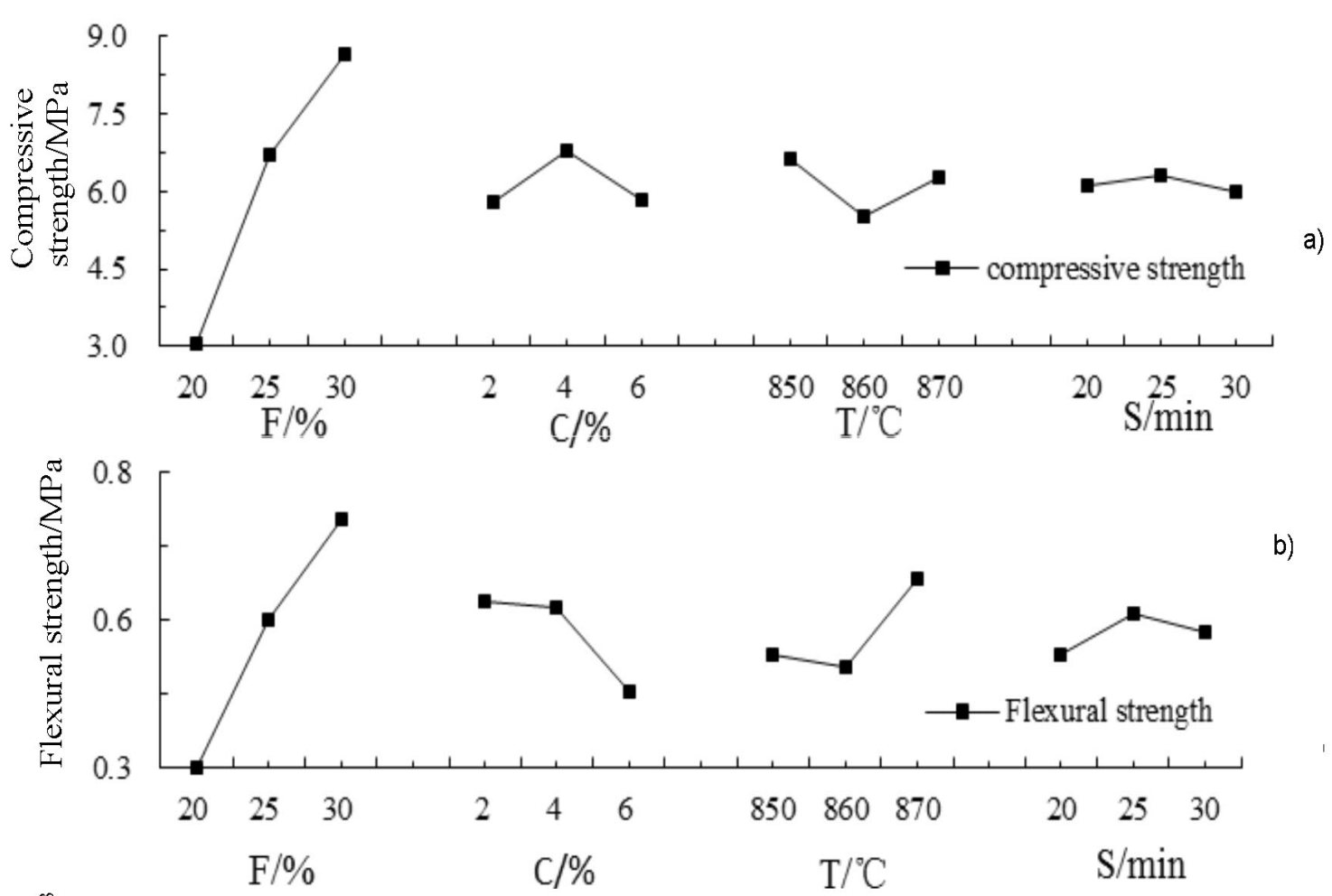

b)
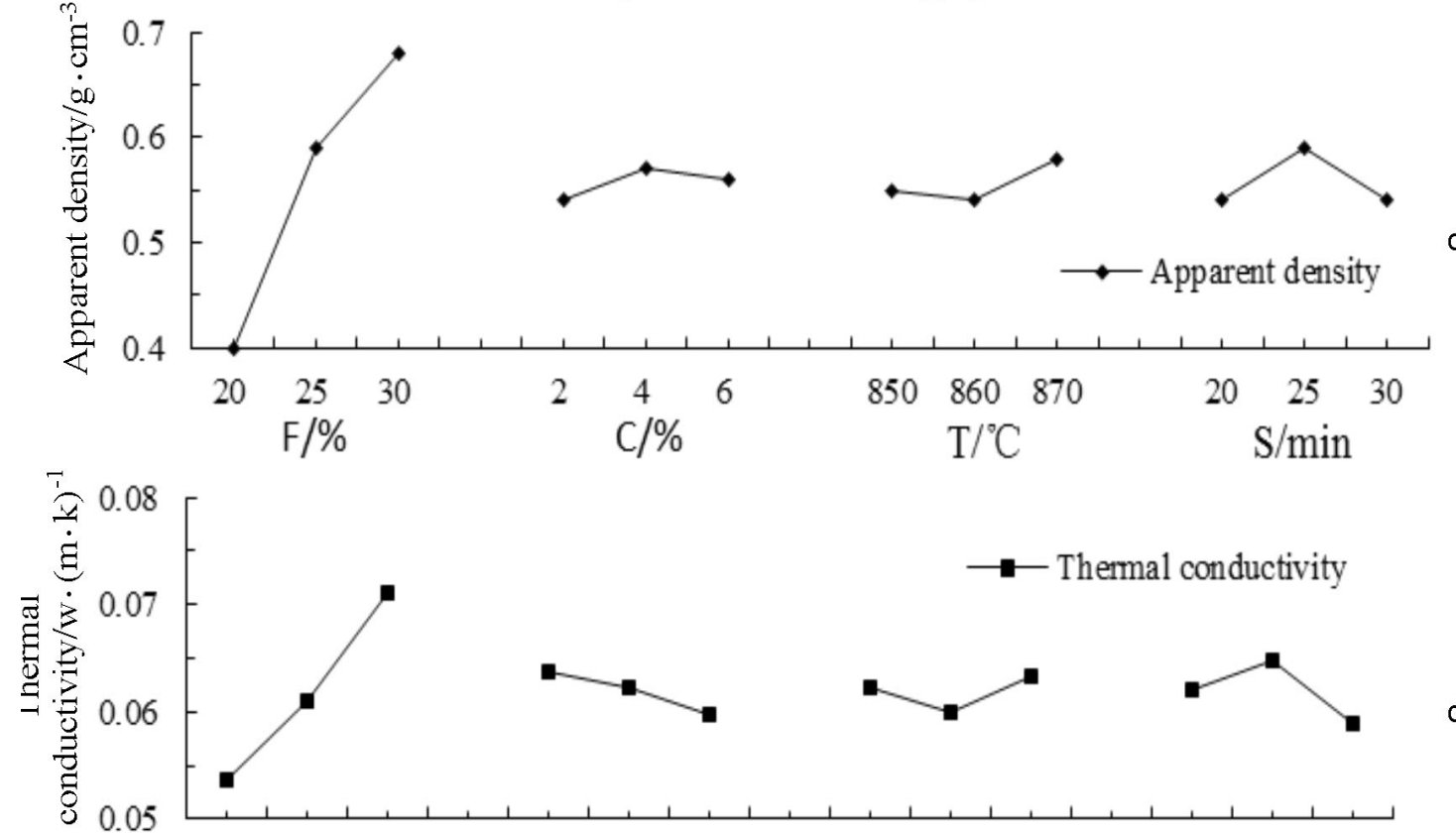

d)

Fig.1 Effects of the factors on properties of foam glass samples. (a) Effect of various factors on compressive strength; (b) effect of various factors on flexural strength; (c) effect of various factors on apparent density; (d) effect of various factors on thermal conductivity.

\subsection{Analysis of factors affecting performance}

The compressive strength, flexural strength, apparent density and thermal conductivity were taken as test indexes and the range analysis method of orthogonal experiment was used to analyze the factors affecting the performance of 9 groups of foam glass. The relationship curve between the 4 factors of the content of fly ash, the content of sodium carbonate, the foaming temperature and the foaming time and the average values of the corresponding test indexes at 3 levels was drawn as shown in Fig. 1.

The influence of 4 factors that were the amount of fly ash, sodium carbonate, foam- 
Table 2. Factors and levels of orthogonal experiment

\begin{tabular}{|c|c|c|c|c|}
\hline \multirow{2}{*}{ Level } & \multicolumn{3}{|c|}{ Factors } \\
\cline { 2 - 3 } & \multicolumn{2}{|c|}{$\omega / \%$} & Foaming temperature,${ }^{\circ} \mathrm{C}$ & Foaming time, min \\
\cline { 2 - 3 } & Fly ash & $\mathrm{Na}_{2} \mathrm{CO}_{3}$ & & \\
\hline \multirow{2}{*}{1} & 20 & 2 & 850 & 20 \\
2 & 25 & 4 & 860 & 25 \\
3 & 30 & 6 & 870 & 30 \\
\hline
\end{tabular}

Note: $\omega$ is mass fraction.

Table 3. Results of orthogonal experiment

\begin{tabular}{|c|c|c|c|c|c|c|c|c|}
\hline $\begin{array}{l}\text { Sample } \\
\text { No. }\end{array}$ & $\mathrm{F}$ & $\mathrm{C}$ & $\mathrm{T}$ & $\mathrm{S}$ & $\begin{array}{c}\text { Compressive } \\
\text { strength, } \mathrm{MPa}\end{array}$ & $\begin{array}{c}\text { Flexural } \\
\text { strength, MPa }\end{array}$ & $\begin{array}{l}\text { Apparent den- } \\
\text { sity, } \mathrm{g} \cdot \mathrm{cm}^{-3}\end{array}$ & $\begin{array}{l}\text { Thermal conduc- } \\
\text { tivity, } \mathrm{w} \cdot(\mathrm{m} \cdot \mathrm{k})^{-1}\end{array}$ \\
\hline $\mathrm{Z1}$ & 20 & 2 & 850 & 20 & 3.18 & 0.29 & 0.37 & 0.056 \\
\hline $\mathrm{Z} 2$ & 20 & 4 & 860 & 25 & 3.23 & 0.32 & 0.42 & 0.055 \\
\hline Z3 & 20 & 6 & 870 & 30 & 2.70 & 0.30 & 0.41 & 0.050 \\
\hline $\mathrm{Z4}$ & 25 & 2 & 860 & 30 & 5.61 & 0.56 & 0.54 & 0.058 \\
\hline $\mathrm{Z} 5$ & 25 & 4 & 870 & 20 & 7.45 & 0.65 & 0.61 & 0.063 \\
\hline $\mathrm{Z} 6$ & 25 & 6 & 850 & 25 & 7.05 & 0.45 & 0.62 & 0.062 \\
\hline $\mathrm{Z7}$ & 30 & 2 & 870 & 25 & 8.63 & 0.90 & 0.72 & 0.077 \\
\hline $\mathrm{Z8}$ & 30 & 4 & 850 & 30 & 9.64 & 0.73 & 0.67 & 0.069 \\
\hline $\mathrm{Z9}$ & 30 & 6 & 860 & 20 & 7.72 & 0.53 & 0.65 & 0.067 \\
\hline
\end{tabular}

Note: F, C, T and S are fly ash, sodium carbonate, foaming temperature and foaming time, respectively.

ing temperature and foaming time on compressive strength, flexural strength, apparent density and thermal conductivity were quite different according to Fig. 1. When the compressive strength, flexural strength and thermal conductivity were used as the test indexes, the 4 factors were basically consistent with the above 3 test indexes. The amount of fly ash had the greatest influence on compressive strength, flexural strength and thermal conductivity. The compressive strength, flexural strength and thermal conductivity increased with the increase of fly ash content. Compressive strength, flexural strength and thermal conductivity are less affected by the other 3 factors. When the content of fly ash was $20 \%, 25 \%$ and $30 \%$, the average values of compressive strength were $3.03 \mathrm{MPa}, 6.70$ $\mathrm{MPa}$ and $8.66 \mathrm{MPa}$, the average values of flexural strength were $3.03 \mathrm{MPa}, 6.70 \mathrm{MPa}$ and $8.66 \mathrm{MPa}$ and the average values of thermal conductivity were $0.054 \mathrm{w}$, (moK), $0.061 \mathrm{w},(\mathrm{moK})$ and $0.071 \mathrm{w},(\mathrm{moK})$. The content of fly ash was on the basis of $20 \%$, when the content of fly ash increased by $5 \%$, the compressive strength increased by $120.75 \%$ and $29.24 \%$, the flexural strength increased by $82.42 \%$ and $30.12 \%$, and the thermal conductivity increased by $13.67 \%$ and $16.39 \%$, respectively. When the apparent density was used as the test index, the influence of foaming temperature was the biggest, followed by the amount of sodium carbonate, and the smallest influence was the amount of fly ash. The influence of the 4 factors on the apparent density of foam glass at 3 levels was firstly increased and then decreased, and the apparent density fluctuated between $0.37 \mathrm{~g} / \mathrm{cm}^{3}$ and $0.72 \mathrm{~g} / \mathrm{cm}^{3}$.

Taken together, foam glass products with high strength, light weight, good heat insulation performance and low production cost could be obtained by adopting the preparation process with fly ash content of $25 \%$, sodium carbonate content of $4 \%$, foaming temperature at $850^{\circ} \mathrm{C}$ and foaming time of $20 \mathrm{~min}$.

\subsection{Pore structure analysis}

The instrument of Occhio Scan 600 was used to scan and analyze the pore structure on the area of $20 \times 20 \mathrm{~mm}^{2}$ at the geometry center of the 9 samples, and to characterize the pore structure of the sample as shown in Fig. 2.

It could be seen from Fig. 2 that the morphology of pore structure from the 9 groups were quite different and it was indicated that the content of fly ash, firing 


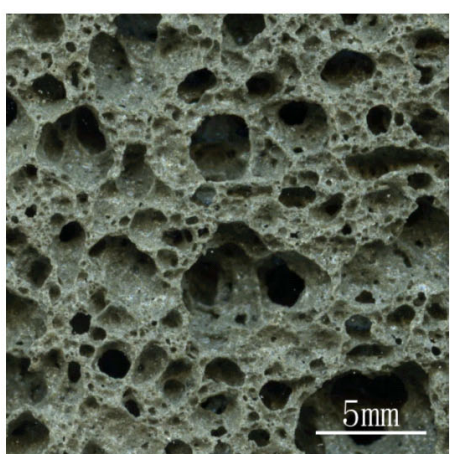

(a) Z1

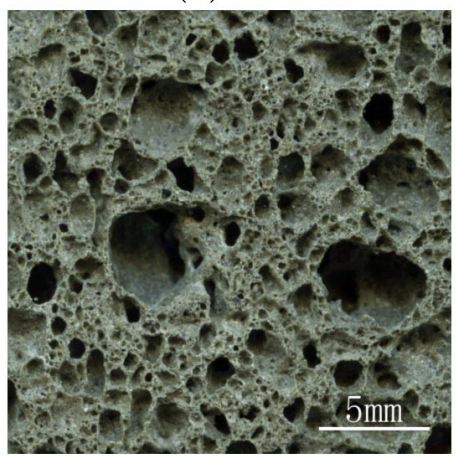

(d) Z4

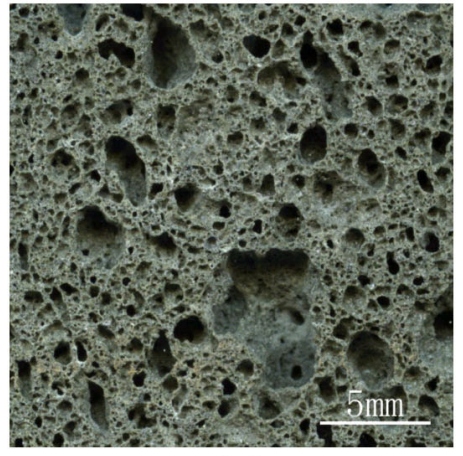

(g) Z7

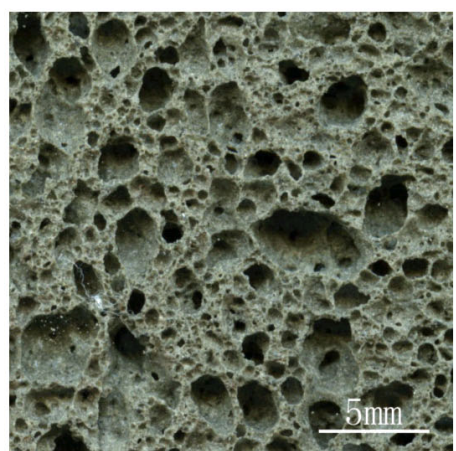

(b) Z2

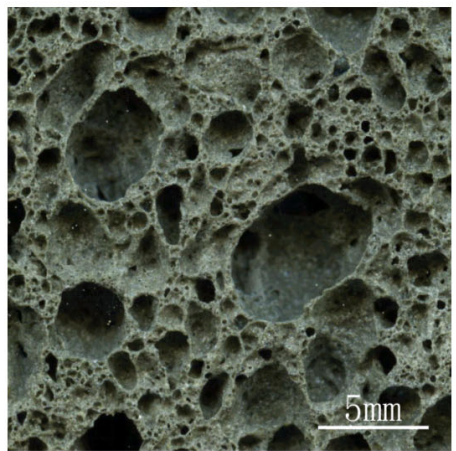

(e) Z5

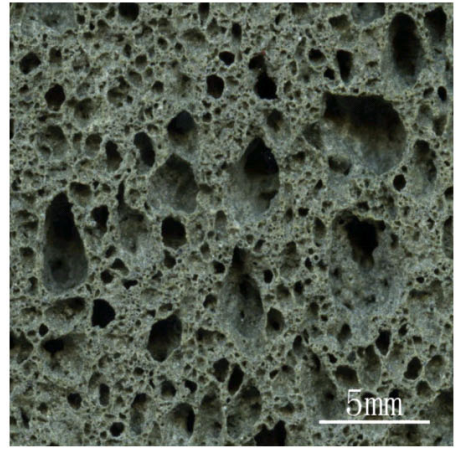

(h) Z8

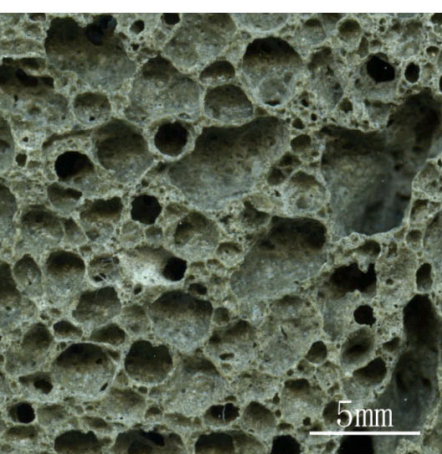

(c) Z3

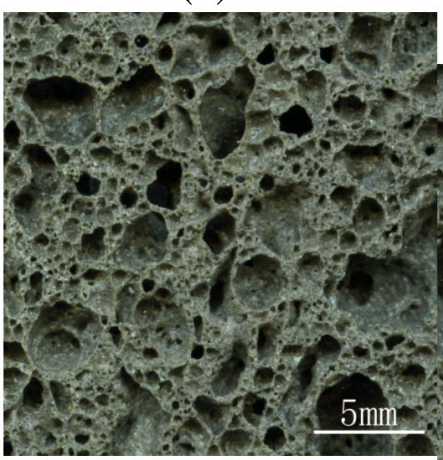

(f) Z6

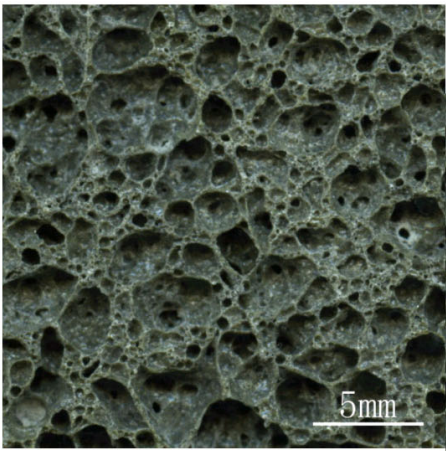

(i) Z9

Fig.2 Pore structure diagram of foam glass samples.

temperature, amount of foaming agent and foaming time had remarkable influence on the pore structure. The pore walls of samples (Z1 and Z2) were quite thick, the number of macroscopic pores (visible to the naked eye) was very small, the pore structure distribution was relatively uniform when the firing temperature was $850 \sim 860^{\circ} \mathrm{C}$, the amount of sodium carbonate (foaming agent) was $2 \sim 4 \%$ and the foaming time was shorter 20 25 min. The pore walls of samples (Z3 Z9) was thinner than Z1 and Z2, and the number of pores was also increased obviously with the increase of firing temperature, sodium carbonate content and the extension of foaming time. If the amount of sodium carbonate was more or foaming time was longer when the firing temperature reached $870^{\circ} \mathrm{C}$, the number of connected pores in the sample (Z3, Z5) would increase significantly. If the amount of sodium carbonate was decreased and the foaming time was shortened, the number of connected pores would decrease.

The pore sizes of these samples were statistically analyzed by particle size analysis software Nano Measurer. The aperture was divided into 6 grades interval that were $d \geq 3 \mathrm{~mm}$, $2 \mathrm{~mm} \leq d<3 \mathrm{~mm}, 1 \mathrm{~mm} \leq d<2 \mathrm{~mm}, 0.5 \mathrm{~mm} \leq d<1 \mathrm{~mm}$, $0.1 \mathrm{~mm} \leq d<0.5 \mathrm{~mm}, \quad 0.01 \mathrm{~mm} \leq d<0.1 \mathrm{~mm}$. The number of apertures in each range was counted, and the standard deviation of total pore diameter, average pore diameter and pore size were calculated as shown in Table 4 . 
Zipeng Qin et al. / Optimization of preparation ...

Table 4 Statistical results of pore sizes of foam glass samples

\begin{tabular}{||c|c|c|c|c|c|c|c|c|c|c|c||}
\hline \multicolumn{2}{|c|}{ Sample No. } & $\mathrm{Z} 1$ & $\mathrm{Z} 2$ & $\mathrm{Z} 3$ & $\mathrm{Z} 4$ & $\mathrm{Z} 5$ & $\mathrm{Z} 6$ & $\mathrm{Z} 7$ & $\mathrm{Z} 8$ & $\mathrm{Z} 9$ \\
\hline $\begin{array}{c}\text { Aperture } \\
\text { number }\end{array}$ & 1 & $\mathrm{~d} \geq 3 \mathrm{~mm}$ & 1 & 0 & 1 & 4 & 4 & 4 & 2 & 1 & 0 \\
& 2 & $2 \mathrm{~mm} \leq \mathrm{d}<3 \mathrm{~mm}$ & 6 & 4 & 17 & 5 & 10 & 9 & 1 & 11 & 4 \\
& 3 & $1 \mathrm{~mm} \leq \mathrm{d}<2 \mathrm{~mm}$ & 46 & 24 & 49 & 46 & 55 & 48 & 37 & 46 & 33 \\
& 4 & $0.5 \mathrm{~mm} \leq \mathrm{d}<1 \mathrm{~mm}$ & 79 & 72 & 66 & 94 & 68 & 78 & 91 & 92 & 60 \\
& 5 & $0.1 \mathrm{~mm} \leq \mathrm{d}<0.5 \mathrm{~mm}$ & 66 & 54 & 15 & 113 & 99 & 25 & 21 & 35 & 21 \\
& 6 & $0.01 \mathrm{~mm} \leq \mathrm{d}<0.1 \mathrm{~mm}$ & 0 & 0 & 0 & 0 & 1 & 1 & 0 & 3 & 0 \\
\hline
\end{tabular}

As experiment showed, when the firing temperature was $850 \sim 860^{\circ} \mathrm{C}$, the amount of sodium carbonate (foaming agent) was $2 \sim 4 \%$ and the foaming time was $20 \sim 25 \mathrm{~min}$, the average pore diameter and standard deviation of pore size counted from samples (Z1, Z2) were relatively small. The average pore diameter and the standard deviation of pore size of samples (Z3 Z9) increased in different degrees with the increase of firing temperature, the increasing amount of sodium carbonate and the extension of foaming time. When the firing temperature was $870^{\circ} \mathrm{C}$, the content of sodium carbonate was $6 \%$ and the foaming time was $30 \mathrm{~min}$, the average pore size of the samples reaches the maximum that is $1.11 \mathrm{~mm}$, and the standard deviation of the pore diameter was close to $0.60 \mathrm{~mm}$. The influence of the amount of sodium carbonate on average pore size was also significant. When the amount of sodium carbonate was $6 \%$, the average pore size of samples (Z3, Z6 and $\mathrm{Z9}$ ) reached $1.11 \mathrm{~mm} \quad\left(870^{\circ} \mathrm{C}\right), \quad 0.99 \mathrm{~mm} \quad\left(860^{\circ} \mathrm{C}\right)$ and $0.89 \mathrm{~mm}\left(850^{\circ} \mathrm{C}\right)$ respectively.

The distribution of the por the relationship curves were drawn between aperture levels and number of corresponding pores as shown in Fig. 2.

As shown in Fig. 3, the number distribution of pore sizes was approximately normal distribution within 6 grades interval. The number of pore sizes from all samples at 3,4 and 5 grades was above $85 \%$ and it showed the pore size of the sample was mainly distributed in the range of $0.1 \sim 2.0 \mathrm{~mm}$.

Average pore size is an important parameter to reflect the size of pore structure and quality of foam glass[23]. The average pore size was used as the evaluation index and factors that affected the average pore size of foam glass from 9 groups were analyzed by range analysis of orthogonal ex-

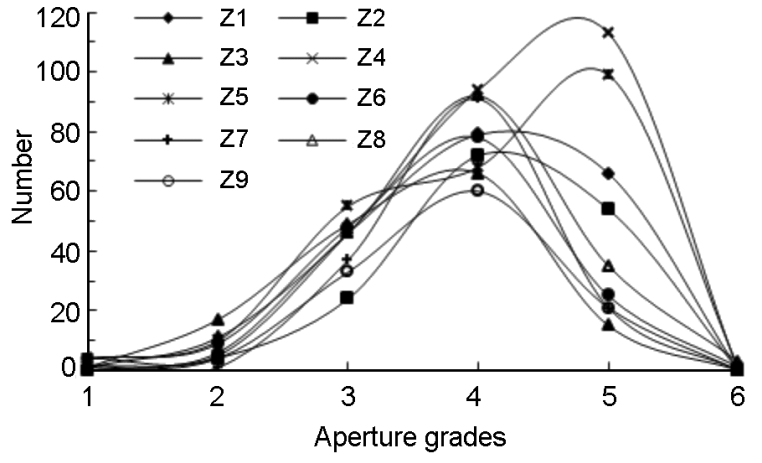

Fig.3 Pore size distribution of foam glass samples

periment. The relationship curve between the 4 factors of the content of fly ash, the content of sodium carbonate, the foaming temperature and the foaming time and the average values of corresponding index at 3 levels was drawn as shown in Fig. 4.

As shown in Fig. 4, the influence of the amount of sodium carbonate on the average pore size was the biggest, followed by the foaming temperature, and the influence of the amount of fly ash on the average pore size was the least. When the dosage of sodium carbonate was $2 \%, 4 \%$ and $6 \%$, the average pore diameters were $0.78 \mathrm{~mm}, 0.81$ $\mathrm{mm}$ and $1 \mathrm{~mm}$ respectively. The average pore diameters increased by $3.85 \%$ and $23.46 \%$ with an increase of $2 \%$ when the amount of sodium carbonate was on the basis of $2 \%$. The decomposition reaction of sodium carbonate had already occurred at $850^{\circ} \mathrm{C}$, in theory, each of the decomposed sodium carbonate particles produced a tiny blowhole. Therefore, the amount of sodium carbonate increased, the number of sodium carbonate particles increased, and the number of pores increased. However, when the amount of sodium carbonate increased to a 


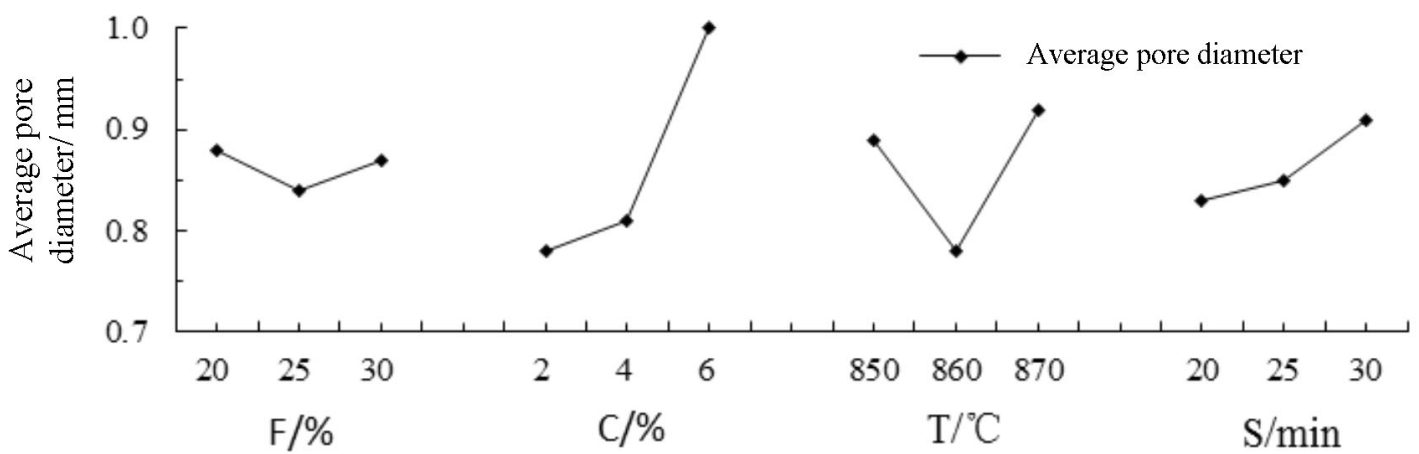

Fig.4 Effect of the factors on average pore sizes of foam glass samples
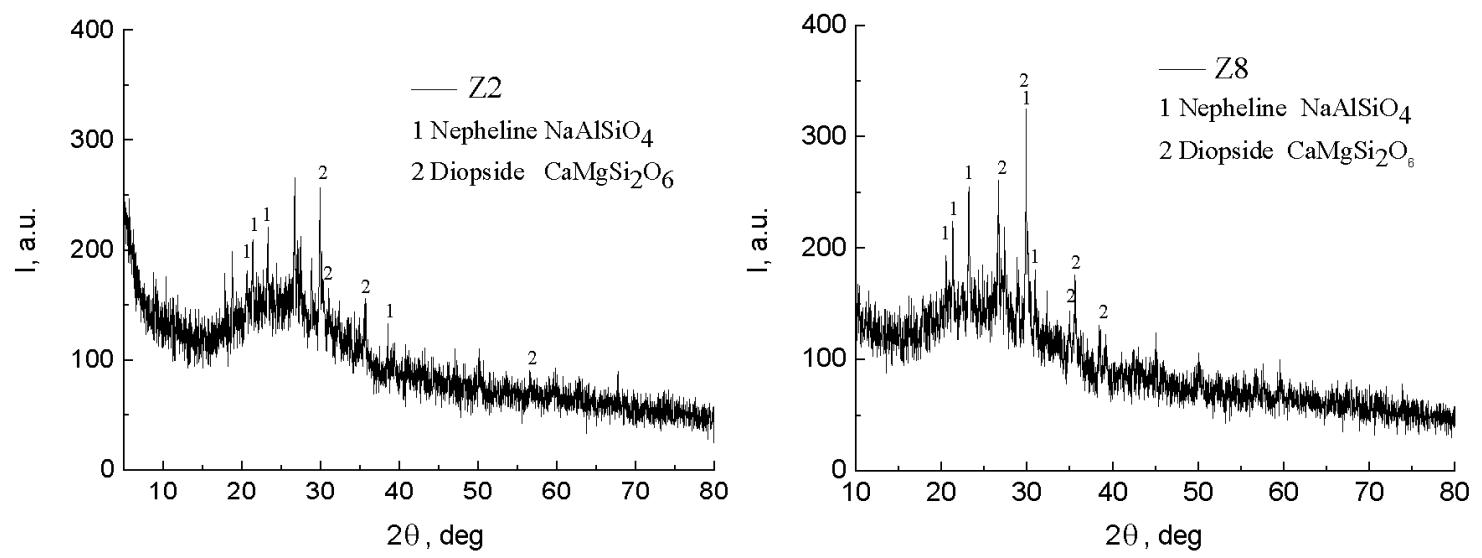

Fig. 5. XRD analysis of partial foam glass samples.

certain extent, the distribution of sodium carbonate particles in the body was relatively dense and the pore spacing was smaller after the decomposition reaction of sodium carbonate particles occurred. The pore wall formed by the reaction was thinner and the pore wall was easy to break under the action of the gas pressure. Thus, the sizes of the connected pores were enlarged, so that the average pore sizes of the samples increased, the number of pores decreased, and the pore structure changed. Since the distribution of sodium carbonate particles in the samples was random, the above process was stochastic as well. The randomness was reflected in the macroscopic physical and mechanical properties of the samples, which leads to the discreteness of the physical and mechanical properties of the samples.

\subsection{Microstructure analysis}

In order to determine the crystallization degree, crystal type and the influence of various factors on the phase of foam glass, XRD analysis on 2 sets of samples (Z2 and Z8) was carried out as shown in Fig. 5.
According to Fig. 5, there was a certain amount of crystal precipitation in the process of sintering, and the main phase was nepheline $\left(\mathrm{NaAlSiO}_{4}\right)$, the second phase was diopside $\left(\mathrm{CaMgSi}_{2} \mathrm{O}_{6}\right)$.

In order to investigate the crystal precipitation in fly ash foam glass, some of the samples were scanned by electron microscope, and the scanning Fig.s were shown in Fig. 6 .

According to Fig. 5, there are granular and blocky crystals in the sample of foamed glass samples. Thermogravimetric analysis of the literature [24] showed that the thermal stability of fly ash was excellent, and the chemical reaction did not happen at room temperature to $1200^{\circ} \mathrm{C}$, but the fly ash had obvious chemical reaction at $789-859^{\circ} \mathrm{C}$ after adding sodium carbonate. When foam glass was fired at $850^{\circ} \mathrm{C}$, a large number of hollowed-out fly ash particles were found in the samples as shown in Fig. 6 (a). This phenomenon indicated that the fly ash had been involved in the chemical reaction at $850^{\circ} \mathrm{C}$. The main chemical compositions of fly ash used in the test were $\mathrm{Al}_{2} \mathrm{O}_{3}$ and $\mathrm{SiO}_{2}$ whose total amount to more than $90 \%$, and the fly ash was mainly composed of mullite 


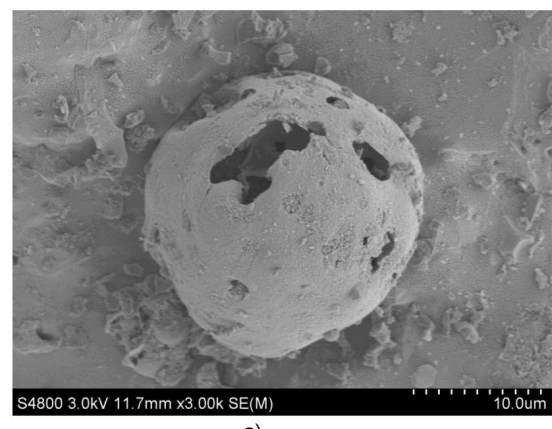

a)

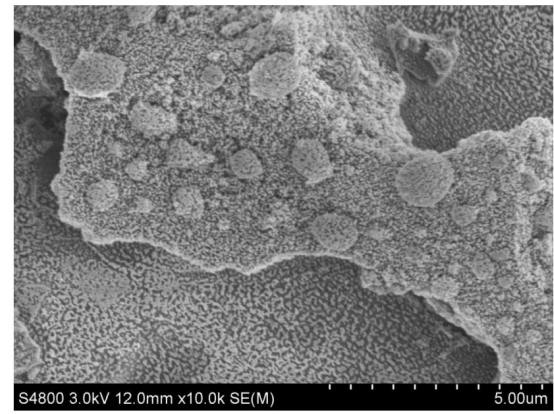

c)

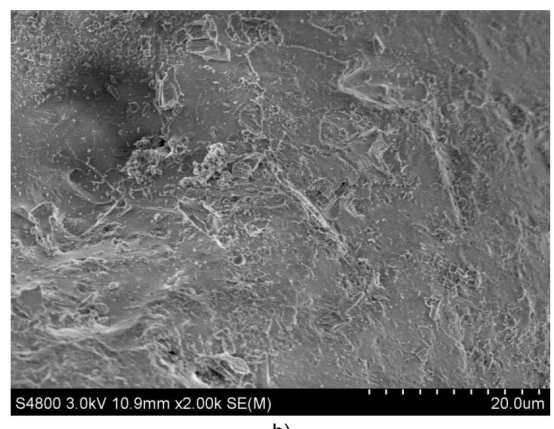

b)

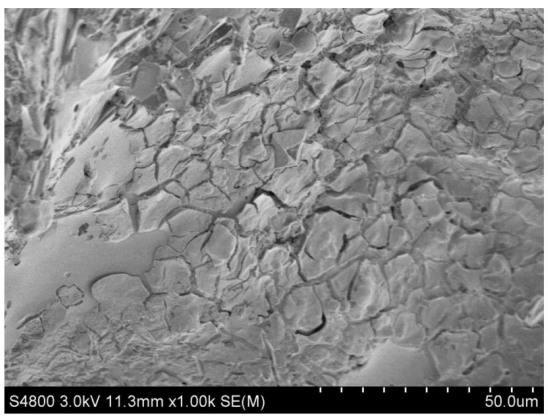

d)

Fig. 6. SEM photographs of partial foam glass samples. (a) Incompletely reacted fly ash particles (Z8); (b) A small amount of granular crystals (Z2); (c) A large number of granular crystals (Z8); (d) Massive crystals (Z8, after acid corrosion)

$\left(\mathrm{Al}_{6} \mathrm{SiO}_{13}\right)$ crystal phase and aluminosilicate glass phase. The sintering temperature used in the experiment was $850-870^{\circ} \mathrm{C}$, the solidsolid reaction occurs in the material at this temperature and $\mathrm{SiO}_{2}$ did not participate in the reaction in the solid state [25], therefore, the main chemical reaction formula of fly ash and sodium carbonate is as follows.

$$
\begin{gathered}
\mathrm{Al}_{6} \mathrm{SiO}_{13}+3 \mathrm{Na}_{2} \mathrm{CO}_{3} \rightarrow \\
2 \mathrm{NaAlSiO}_{4}+4 \mathrm{NaAlO}_{2}+3 \mathrm{CO}_{2} \uparrow
\end{gathered}
$$

Reaction between mullite and sodium carbonate in fly ash at moderate temperature from the above equation produced nepheline whose crystals were gathered together to form granules as shown in Fig. 6 (c). Fig. 6 (d) was obtained by scanning electron microscopy after corroding the Z8 sample with $2 \% \mathrm{HF}$ solution for $45 \mathrm{~s}$. A large number of massive crystals were present in Fig. $6(\mathrm{~d})$, which greatly increases the strength of the sample. Compared with $\mathrm{Z} 8$, the sintering temperature of $\mathrm{Z} 2$ had been increased by $1.18 \%$, the amount of fly ash decreased by $33.33 \%$, the foaming time was shortened by $20 \%$, the amount of sodium carbonate was consistent, however, the mechanical strength of Z2 decreases obviously. From the performance analysis in the above 2.2 section, we can see that the amount of fly ash had the greatest influence on the me- chanical properties of the samples. The amount of mullite in the body is less due to the small amount of fly ash in Z2 samples, and the lack of mullite content resulted in its failure to respond adequately to sodium carbonate. As we can see from Fig. 6 (b), only a small amount of granular crystals were observed in the Z2 sample, and a small amount of bulk crystals were found after $2 \% \mathrm{HF}$ solution corrosion for $45 \mathrm{~s}$. These granular crystals in Z2 samples did not grow sufficiently to form as many crystalline crystals as in Z8 samples. Therefore, the mechanical properties of $\mathrm{Z} 2$ samples were lower than that of $\mathrm{Z} 8$ samples.

According to the above macro and micro analysis, the mechanical properties of foam glass could be improved remarkably by the increase of fly ash content. But the thermal conductivity of the sample would increase significantly after the content of fly ash increas

The influence of the amount of fly ash, sodium carbonate, foaming temperature and foaming time on compressive strength, flexural strength, apparent density and thermal conductivity were quite different. Foam glass products with high strength, light weight, good heat insulation performance and low production cost could be obtained by adopting the preparation process 
with fly ash content of $25 \%$, sodium carbonate content of $4 \%$, foaming temperature at $850^{\circ} \mathrm{C}$ and foaming time of $20 \mathrm{~min}$.

The influence of the amount of sodium carbonate on the average pore size of the samples was the most significant. The average pore diameters increased by $3.85 \%$ and $23.46 \%$ with an increase of $2 \%$ on the basis of the amount at $2 \%$. However, when the amount of sodium carbonate was continuously increased, it was easy to form large holes in the samples, which resulted in the increase of average pore size, the decrease of pore number and the change of pore structure. The distribution of sodium carbonate particles in the sample was random, and porosity and pore structure change were random as well. The randomness would be reflected in the macro physical and mechanical properties of the samples, which made the physical and mechanical properties of the sample have a certain discreteness.

There was a certain amount of crystal precipitation in the process of sintering. The main phase was nepheline and secondary crystalline phase was diopside. The production of crystals greatly improved the mechanical properties of the sample. The increase of the content of fly ash could increase the amount of crystal precipitation, but the thermal conductivity of the samples would increase significantly after the content of fly ash increased continuously, which led to the decrease of the thermal insulation property of the samples. The control of fly ash content was more suitable at $25 \%$ after analysis.

Acknowledgments

This work is supported by the National Natural Science Foundation of China (51468056).

\section{References}

1. Lyuben Lakov, Krasimira Toncheva, Pencho Zlatev, et al, J.Mater. Scie. Techn., 20,147, 2012
2. Chen Bo, Luo Zhiwei, Lu Anxian. Mater. Letters, 65, 3555, 2011.

3. Jakob Konig, Rasmus R Petersen, Yuanzheng Yue, et al., J. Eur. Ceram. Soc., 34,1591, 2014.

4. Rasmus R.Petersen, Jakob Konig, Yuanzheng Yue., J.Non-Crystall. Solids, 456, 49, 2017.

5. Huan Shi, Keqin Feng, Haibo Wang,et al.al., Int. J. Minerals, Metallurg. Mater., 23, 595, 2016.

6. Andrea Ventrella, Federico Smeacetto, Milena Salvo,et al., J.Mater.Eng.Perform, 21, 2380, 2012.

7. Abbasi S, Mirkazemi S M, Ziaee A, et al., Glass Phys.Chem. A., 40,173, 2014.

8. Qu YaNan,Xu Jie,Su ZhenGuo,et al., Ceramic Intern.,42, 2370, 2016.

9. Xinyue Fang, Qie Li,Tao Yang, et al., Constr. Build. Mater.,134,358, 2017.

10. Hrma, P., J.Non-Crystall. Solid., 355, 257, 2009.

11. V. Vaganov, M. Popov, A. Korjakins, et al, Procedia Eng. 172,1204, 2017.

12. Fernandes H R,Tulyaganov D U,Ferreira J M F., Ceramic Intern., 35, 229, 2009.

13. Rasmus R Petersen, Jakob Konig, Yuanzheng Yue, J.Non-Crystall. Solids, 456, 49, 2017.

14. Chen Bo,Wang Keqiang,Chen Xingjun, et al., Mater. Lett.,79, 263, 2012.

15. Qin Zipeng, Li Gang, Ma Yuwei, et al., China Ceramics, 53, 58, 2017.

16. Qin,Zipeng, Ma Yuwei, Li Gang, et al.,New Build. Mater., 6, 88, 2016.

17. QIAN Shuai, LIN Jian, TANG Baoshan, $J$. Chinese Ceram. Soc., 42, 108, 2014.

18. Yingliang Tian,Ping Lu,Suli Zhang, et al., J.Wuhan, Univ. Technol. Mater. Sci. Ed., 31, 538, 2016.

19. Zhou Yu, Feng Keqin, Wang Haibo,et al., J. Sichuan Univ. (Engin. Scie. Ed.), 46, 192, 2014.

20. Huan Shi, Keqin Feng, Haibo Wang, et al., Int. J. Minerals, Metallurg..Mater, 23, 595, 2016.

21. SONG Qiang,Li Gang, Ma Yuwei,et al., J. Shihezi Univ.(Natural Scie), 31, 510, 2013.

22. Qin,Zipeng, Ma Yuwei, Li Gang,et al., NonMetallic Mines, 39, 7, 2016.

23. WU Zhenxian, ZHU Shaofeng, LI Ping, et al., J.Funct. Mater., 45, 2114, 2014.

24. WANG Lihua, WANG Dongsheng, Spectr. Spectr. Anal, 25, 1240, 2005.

25. Peng Hui, Bulletin Mineralogy, 26(S1), 198, 2007. 